\title{
Girişimcilik Niyeti ve Yaşam Doyumunun, Sosyal Zekâ Algısı Bağlamında İncelenmesine Yönelik Bir Araştırma ${ }^{1 *}$
}

\author{
İsmail BAKAN \\ Prof. Dr., Kahramanmaraş Sütçü İmam Üniversitesi, \\ İktisadi ve İdari Bilimler Fakültesi, İşletme Bölümü \\ ibakan63@hotmail.com \\ Orcid ID: https://orcid.org/0000-0001-8644-8778
}

\section{Hamran AMIRLI}

Kahramanmaraş Sütçü İmam Üniversitesi, Sosyal Bilimler Enstitüsü Doktora Öğrencisi hamran.amirli@gmail.com

Orcid ID: https://orcid.org/0000-0003-3619-6562

\section{$\ddot{O} \mathbf{z}$}

Çalışmanın amacı üniversite öğrencilerinin sosyal zekâ düzeylerinin girişimcilik niyetleri ve yaşam doyumları üzerindeki etkisinin tespit edilmesidir. Akdeniz Bölgesinde eğitim veren bir devlet üniversitesinin İktisadi ve İdari Bilimler Fakültesi son sınıfında eğitim gören öğrenciler araştırmanın evrenini oluştururken, araştırmanın örneklemini ise söz konusu öğrencilerden basit tesadüfü yöntemle seçilen 303 öğrenci oluşturmaktadır. Araştırma verileri anket tekniğiyle toplanmıştır. Veri toplayabilmek amacıyla Silvera vd. (2001) tarafından oluşturulan TROMSO sosyal zekâ ölçeği, Linan ve Chen (2009) tarafından oluşturulan girişimcilik niyeti ölçeği ve Diener vd. (1985) tarafından oluşturulan yaşam doyumu ölçeği kullanılmıştır. Anket verilerinin analizi SPSS 21 Paket Programında yapılmıştır. Araştırmanın bulguları bölümünde, sırasıyla katılımcıların demografik özelliklerine ilişkin frekans dağılımlarına, faktör analizi sonuçlarına ve güvenirlilik analizi sonuçlarına yer verilmiştir. Katılımcıların sosyal zekâ düzeyleriyle girişimcilik niyeti ve yaşam doyumu algıları arasındaki ilişkiyi ve etkiyi belirlemek için ise Korelasyon ve Regresyon analizleri yapılmıştır. Analizler sonucunda sosyal zekâ alt boyutlarından sosyal

\footnotetext{
${ }^{1}$ Makale Geliş/Kabul Tarihi: 18.12.2020 / 10.02.2021

* Bu çalışma Kahramanmaraş Sütçü İmam Üniversitesi Sosyal Bilimler Enstitüsü İşletme Ana Bilim Dalında tamamlanan "Sosyal Zekânın Girişimcilik Niyeti ve Yaşam Doyumu Üzerindeki Etkisi: Bir Alan Araştırması” başlıklı yüksek lisans tezinden üretilmiştir. Künye Bilgisi: Bakan, İ. ve Amırlı, H. (2021). Girişimcilik niyeti ve yaşam doyumunun, sosyal zekâ algısı bağlamında incelenmesine yönelik bir araştırma. Kahramanmaraş Sütçü Imam Üniversitesi Sosyal Bilimler Dergisi, 18(1), 497-527. DOI: 10.33437/ksusbd.842706
} 
bilgi süreci algısının girişimcilik niyeti ve yaşam doyumu üzerinde olumlu etkisi olduğu görülürken, sosyal zekânın bir diğer alt boyutu olan sosyal farkındalık ile girişimcilik niyeti ve yaşam doyumu arasında ise istatistiksel olarak herhangi bir ilişki tespit edilememiştir.

Anahtar Kelimeler: Sosyal Zekâ, Girişimcilik Niyeti, Yaşam Doyumu.

\title{
A Study on the Investigation of Entrepreneurial Intention and Life Satisfaction in the Context of Social Intelligence Perception
}

\begin{abstract}
The aim of the study is to determine the effect of university students' social intelligence levels on their entrepreneurial intentions and life satisfaction. While senior students studying at the Faculty of Economics and Administrative Sciences of a state university providing education in the Mediterranean Region constitute the population of the study, the sample of the study consists of 303 students selected by the simple random method. The data of the research were collected by questionnaire method. In order to collect data, the TROMSO social intelligence scale created by Silvera et al. (2001), the entrepreneurial intention scale created by Linan and Chen (2009) and the life satisfaction scale created by Diener et al. (1985) were used. The analysis of the survey data was made in the SPSS 21 Package Program. In the section of the findings of the study, frequency distributions related to the demographic characteristics of the participants, factor analysis results and reliability analysis results are included respectively. Correlation and regression analyses were performed to determine the relationship and effect between participants ' social intelligence levels and their perception of entrepreneurial intent and life satisfaction. As a result of the analyzes, it was seen that social information process perception, one of the sub-dimensions of social intelligence, had a positive effect on entrepreneurial intention and life satisfaction, while no statistically significant relationship was found between social awareness, another sub-dimension of social intelligence, and entrepreneurial intention and life satisfaction.
\end{abstract}

Keywords: Social Intelligence, Entrepreneurial Intent, Life Satisfaction.

\section{GíRIŞ}

Psikolojinin yeni alanlarından biri olan sosyal zekâ, son yıllarda çekici ve yaygın yönleri nedeniyle psikologların ve psikiyatristlerin yanı sıra yönetim bilimciler gibi çeşitli alanlardaki diğer uzmanların da dikkatini çekmiştir (Ebrahimpoor vd., 2013: 2). Bu uzmanlardan bazıları kavram ile ilgili birçok 
çalışma (Thorndike and Stein, 1937; Walker and Foley, 1973; Marlowe, 1986; Kihlstrom and Cantor, 2000; Silvera vd., 2001; Bar-On vd., 2006; Goleman, 2007; Ebrahimpoor vd., 2013) gerçekleştirmişlerdir. Yapılan çalışmalardan birinde (Ebrahimpoor vd., 2013: 2) sosyal zekâ, "başkalarıyla ilişki kurma, kişisel bilgi, başkalarının duyguları, mizaçları ve teşvikleri hakkında yargılama yeteneği, etkili sosyal performans, sempati duyma ve sözel olmayan işaretleri çözme becerisi” şeklinde tanımlanmıştır.

Birtakım bilim insanına göre girişimcilik doğuştan kazanılan bir yetenektir; bazılarına göre ise girişimcilik yaşam süresi boyunca sonradan öğrenilmektedir (Şeşen ve Basım, 2012: 21). Ayrıca, girişimcilik niyeti ile ilgili yapılan araştırmalar sonucunda da girişimcilik niyetini etkileyen birçok faktörün olduğu ifade edilmiştir. Literatürde, girişimcilik niyetini etkileyen faktörlere yer verilmiş olup bu faktörlerden bazıları şunlardır; motivasyonel değerler (Kellermanns and Eddleston, 2006; Naktiyok ve Timuroğlu, 2009), kişisel tutum ve algılanan davranış (Kalkan, 2011; Ferreira, vd., 2012), aile (İrmiş ve Barutçu, 2012; Çelik vd., 2014), cinsiyet (İrmiş ve Barutçu, 2012; Çiçek ve Durna, 2012), öz yeterlilik ve öz saygı (Iş̧1k ve Çiçek, 2020), kontrol odağı ve öz yeterlilik (Şeşen ve Basım, 2012; Özler vd., 2017), duygusal zeka (Zampetakis vd., 2008; Timuroğlu ve Akpunar, 2017; Durak, 2018), tükenmişlik düzeyi (Yıldırım vd., 2016), girişimcilik kapasitesi (Rashid vd., 2012; Çetin ve Taşdemir, 2017) ve ekonomi okuryazarlığı (Kâhya ve İmamoğlu, 2015).

Sosyal yönden kendini geliştirip girişimcilik hedeflerine ulaşmaya çalışan üniversite öğrencilerinin yaşam doyumları bu durumdan etkilenecektir. Bakan ve Güler (2017: 1)'e göre yaşam doyumu, bireyin kendi belirlediği ölçütlere göre yaşam şartlarını algılayışı ve buna bir değer yüklemesidir. Bu bağlamda kişinin sahip olduğu sosyal zekâsı yaşam doyumunu etkileyecektir.

Yüksek sosyal zekâya sahip öğrencilerin, sosyal ortamlarda iyi ilişkiler oluşturabilen, başarıya daha kolay ve zamanında ulaşabilen, doğru kariyer seçimi yapabilen ve kariyerinde daha hızlı yükselebilen bireyler olduğu düşünülmektedir. Ayrıca, öğrencilerin sosyal zekâ ve bireylerarası ilişkilerde donanımlı olmaları ve kolayca iletişim kurmalarının, girişimcilik niyetleri ve yaşam doyumları bakımından da önem arz ettiği düşünülmektedir.

Söz konusu bu bilgiler doğrultusunda araştırmanın amacı; son sınıf İ̈BF öğrencilerinin sosyal zekâ ile girişimcilik niyeti ve yaşam doyumu düzeyleri arasında ilişki olup olmadığını tespit etmek ve sosyal zekânın, bireylerin girişimcilik niyeti ve yaşam doyumu üzerindeki etkisini incelemektir. Nicel araştırma yöntemi kullanılmış olup, araştırma verileri anket tekniği ile elde edilmiştir. Anketler Akdeniz Bölgesinde eğitim veren bir devlet üniversitesinin 
İktisadi ve İdari Bilimler Fakültesi son sınıf öğrencilerine uygulanmış, elde edilen verilerin analizi ile araştırma hipotezleri test edilmiştir.

\section{KAVRAMSAL ÇERÇEVE}

\section{Sosyal Zekâ}

Soyut bir yapıya sahip olan zekâ kavramıyla ilgili senelerdir birçok çalışma yapılmaktadır. Bu nedenle, kavram daima sınırları saptanmaya çalışılan, sorgulanan canlı niteliğe sahip bir yapı olarak kalmaktadır. Bilimsel alanda Latince "intelligence” (inter-legentia) olarak kullanılan zekâ sözcügünü ilk defa ortaya atan Marcus Tullius Cicero olmuştur. Cicero, zekâ (intelligence) sözcüğünün Aristoteles'in "dia-noesis" teriminin neredeyse aynısı olduğunu belirtmiştir (Spatar, 1995: 6). Ardından 1800'lü yıllarda bu kavram ile ilgili araştırmalar artmış, farklı görüşler ortaya konulmuş, değişik sınıflamalar yapılmış ve etkileri günlük yaşantımıza şiddetli bir şekilde girmiştir (Bümen, 2004: 1).

Fransız filozof Descartes zekâ kavramıla ilgili ilk tanım yapanlardan biridir. Descartes zekâyı "gerçeği yanlıştan ayırma yeteneği" olarak tanımlamıştır (Salovey and Mayer, 1990: 186). Bingham (1937) ise, zekâ kavramının bir yapının yeni sorunları giderme yeteneğini ifade etmek için kullanılması gerektiğini söylemiştir (Akt. Legg and Hutter, 2006: 4).

Sosyal zekâ kavramı ise, akademik olarak ilk defa Dewey tarafından 1909 yılında yazılmış olan "Eğitimde Ahlaki İlkeler" isimli eserde "sosyal durumları gözlemleme ve anlama gücü” olarak tanımlanmıştır (Dewey, 1909: 43). Thorndike (1920) sosyal, mekanik ve soyut zekâ kavramları arasında sosyal zekâyı popülerleştirmiş̦tir. Thorndike sosyal zekâyı "insanları anlama, yönetme yeteneği ve insan ilişkilerinde mantıklı hareket etme" olarak tanımlamıştır (Akt. Wawra, 2009: 164). Daha sonraki yıllarda sosyal zekâ kavramıyla ilgili yapılan tanımlardan bazıları da şu şekildedir:

- "Diğer insanları ve onların farklı sosyal durumlara nasıl tepki vereceklerini anlama yeteneğidir" (Silvera vd., 2001: 314).

- "Diğer insanlar ile ilişki kurma; onların inanç, duygu ve davranışlarını anlama yeteneğidir" (Parales-Quenza, 2006: 43).

- "Bireyin sosyal etkileşimleri anlamasına ve onlarla amaçlı ve etkili bir şekilde baş etmesine yardımcı olan bir yetenektir" (Habib vd., 2013: 68). Tanımlardan da anlaşılacağı üzere, sosyal zekânın herkes tarafindan kabul edilen bir tanımı konusunda fikir birliğine varılamamıştır (Doğan ve Çetin, 2009: 693). 
Buna paralel olarak, kavram ile ilgili mutabakata varılamayan diğer bir konu da, kavramın hangi boyutlardan oluştuğu ile ilgilidir (Doğan ve Çetin, 2009: 694; İlhan ve Çetin, 2014: 6). Örneğin Orlik (1978) sosyal zekânın beş bileşenden oluştuğunu ileri sürmüş ve bunları (1) diğer insanların içsel durumları ve ruh hallerine ilişkin algıları, (2) insanlarla anlaşma becerisi, (3) sosyal hayatın norm ve kuralları hakkında bilgi sahibi olma, (4) karmaşık sosyal durumlar karşısında duyarlılık ve (5) diğer insanlara hükmetmek için sosyal tekniklerin kullanımı şeklinde sıralamıştır (Akt. Kozmitzki and John, 1993: 13). Marlowe (1986: 5355), sosyal zekânın (1) kişisel tutum, (2) sosyal beceriler, (3) empati becerileri, (4) duygusal anlamlılık ve (5) sosyal kaygı olarak adlandırılan beş boyutlu bir yapıya sahip olduğunu belirtmiştir. Kozmitzki ve John (1993: 13), Orlik'in ileri sürdüğü bileşenlere (6) bakış açısı edinme ve (7) sosyal uyum bileşenlerini eklemişlerdir. Silvera vd. (2001: 316), öne sürdükleri sosyal zekâ modelinde üç boyutlu bir yapı öngörmüşlerdir: (1) sosyal bilgi süreci, (2) sosyal beceri ve (3) sosyal farkındalık. Goleman (2019: 108) ise sosyal zekânın (1) sosyal farkındalık ve (2) sosyal beceri olmak üzere iki boyutlu olduğunu belirtmiştir.

Yüksek sosyal zekâ düzeyine sahip olan insanlar düşük sosyal zekâ düzeyine sahip olan insanlara göre diğer insanların sosyal tepkilerini daha doğru bir şekilde tahmin ederler (Neuringer, 1991: 549). Sosyal zekâ düzeyi yüksek olan insanların başkalarının hislerine, korkularına, ilgilerine ve inançlarına empati ile yaklaşma, onları muhakeme etmeden dinleme ve başarılarını yükseltmelerinde destekleme isteği içinde bulundukları iddia edilmektedir (Başaran, 2004: 11). Toplumda olumlu değişiklikler yaratmaya yardımcı olan (Joseph and Lakshmi, 2010: 18) yüksek sosyal zekâya sahip insanların özelliklerinden bazıları; (1) akranlarıyla ya da farklı yaş grubundan olan insanlarla birlikte zaman geçirmekten hoşlanma, (2) diğer insanları konuşarak etkileyebilme, (3) farklı kültür ve yaşam şekilleri konusunda ilgili olma, (4) güçlü bir espri yeteneğine sahip olma, (5) davranışlarının sonuçlarını değerlendirebilme, (6) sözel ve bedensel dili etkili bir şekilde kullanma, şeklinde sıralanabilir (Yavuz, 2001: 160).

\section{Girişimcilik Niyeti}

Yeni bir kavram olarak değerlendirilen girişimcilik ve girişimci kavramının tarihçesi aslında 18. Yüzyıla kadar dayanmaktadır. Girişimcilik kavramını ilk defa 1755 y1lında "belirsizliğin hükmettiği ekonomik sistemde kar etme girişimi ve risk alma” olarak ifade eden R.Cantillon (Bakan vd., 2017: 121), henüz netleşmemiş bir bedelle satmak için üretim faktörlerini satın alan ve bu faktörleri bir araya getirerek ürün veya hizmet üretimi yapan kişiyi ise girişimci olarak tanımlamıştır (Işık, 2019: 596). A.Smith ise 1776 yılında yayınladığ "Ulusların Zenginliği (The Wealth of Nations)" adlı kitabında girişimciyi (Sciascia and De Vita, 2004: 4): 
- Riski araştırma faaliyetinde bulunduğu için maceracı;

- Gelecek ile ilgili öngörüde bulunup planlar yaptığı ve proje hazırlayabildiği için proje sahibi;

- Mantıklı riskler alan ve geri dönüşünün olacağına inandığı yatırımlar yaptığı için yükümlülük ve risk üstlenen kişi şeklinde tanımlamıştır.

Girişimcilik kavramıyla ilgili 2000'li yıllarda yapılmış olan bazı tanımlara Tablo 1'de yer verilmiştir.

Tablo 1. Girişimcilik Tanımları

\begin{tabular}{|l|l|l|}
\hline \hline Yazar & \multicolumn{1}{|c|}{ Yıl } & \multicolumn{1}{c|}{ Tanım } \\
\hline \hline $\begin{array}{l}\text { Mueller ve } \\
\text { Thomas }\end{array}$ & (2000: 53) & $\begin{array}{l}\text { Girişimcilik, bir fırsatı algılama ve bu firsatı } \\
\text { sürdürmek için bir organizasyon yaratma } \\
\text { eylemidir. }\end{array}$ \\
\hline Ferrante & (2005: 169) & $\begin{array}{l}\text { Girişimcilik, temel olarak belirsiz bir dünyada } \\
\text { karar alma ve daha sonra pazar firsatlarından } \\
\text { yararlanmak için gerekli verileri keşfetme, seçme, } \\
\text { işleme, yorumlama ve kullanma yeteneğidir. }\end{array}$ \\
\hline Hisrich vd., & $(2007: 576)$ & $\begin{array}{l}\text { Girişimcilik, gerekli zaman ve çabayı göstererek } \\
\text { değeri olan yeni bir şey yaratma sürecidir. }\end{array}$ \\
\hline $\begin{array}{l}\text { Balaban ve } \\
\text { Özdemir }\end{array}$ & $(2008: 135)$ & $\begin{array}{l}\text { Girişimcilik, organizasyonlar oluşturarak değer } \\
\text { yaratmaktır. }\end{array}$ \\
\hline $\begin{array}{l}\text { Demirel ve } \\
\text { Tikici }\end{array}$ & $(2010: 225)$ & $\begin{array}{l}\text { Girişimcilik, yeniliklere ve teknik değişimlere yol } \\
\text { gösteren ve bununla birlikte ekonomik gelişmeye } \\
\text { katkıda bulunan, dengesini arz ve talebin } \\
\text { belirlediği, yeni bilginin ürüne ve hizmete } \\
\text { dönüştürüldüğü bir süreçtir. }\end{array}$ \\
\hline Başol vd. & $(2011: 10)$ & $\begin{array}{l}\text { Girişimcilik, firsatları izleme ve onları } \\
\text { keşfettiğinde ortaya çıabilecek riskleri üstlenerek } \\
\text { amacını gerçekleştirme eylemidir. }\end{array}$ \\
\hline \hline
\end{tabular}

William James (1890, 1950)'e göre niyetin, bir bireyin ilgi ve dikkatini kullanarak faaliyet gösteren bağımsız bir zihin yeteneği olduğunu aktaran Bird (1988: 442)'ün kendisi ise niyeti, bir şeye (araçlara) ulaşmak için bireyin dikkatini belirli bir hedefe veya yola doğru yönlendiren bir zihin durumu olarak tanımlamıştır.

Girişimcilik niyeti ise, en basit anlamıyla, "bireyin yeni bir iş kurma niyeti" şeklinde ifade edilebilir (Engle vd., 2008: 38). Karabey (2013: 147)’e göre ise girişimcilik niyeti, "bireyin diğer meslek seçeneklerinden daha çok etrafındaki 
olas1 firsatları değerlendirmesini sağlayacak bir organizasyon yaratma ve teşebbüs başlatma fikrini yansıtmaktadır." Ancak, bir girişime başlama niyeti kısmen beklenen sonuca; yani girişimin başarılı ya da başarısız olmasına ilişkin algısıyla oluşmaktadır. Bu nedenle, sınırlı sayıda insan, başarısız olma ihtimalinin yüksek olduğuna inanmalarına rağmen, girişimcilik faaliyetine katılma niyetinde bulunurlar (Mueller and Dato-On, 2008: 7). Dolayısıyla, bir bireyi girişimci olma doğrultusunda hareket ettiren faktörlerin neler olduğunun belirlenmesi, girişimcilik niyeti kavramının anlaşılabilmesi için oldukça önemlidir (Şeşen ve Basim, 2012: 22).

\section{Yaşam Doyumu}

Yaşam doyumu kavramı hem doyumu hem de mutluluğu içeren bilişsel bir yargılama sürecidir (Deniz, 2006: 1163). İlk kez Neugarten (1961) tarafindan öne sürülen "yaşam doyumu” kavramı (Bakan ve Güler, 2017: 2) ya da bilindik adıyla "mutluluk" (Çevik ve Korkmaz, 2014: 130), son zamanlarda pek çok araştırmacının üzerinde durduğu konulardan birisidir (Behlau, 2010: 10). Yaşam doyumunu tanımlamadan önce "yaşam" ve "doyum" kavramlarının açıklanması uygun olacaktır. Yaşam, "doğumla ölüm arasında yaşanan süre, ömür, hayat" olarak tanımlanmaktadır (TDK, 06.08.2020, www.tdk.gov.tr). "Yapmak" ve "yeterince yapmak" anlamina gelen Latince kökenli doyum kavramı (Sousa and Lyubomirsky, 2001: 669); organizmada açlık, susuzluk, cinsellik vb. gibi hayati ihtiyaçların ya da ilgi, sevgi, samimiyet, başarı vb. gibi ruhsal ihtiyaçların karşılanması sonucu denge durumunun tekrar oluşturulmasıdır (Akandere vd., 2009: 25). Yaşam doyumu ise, "bireyin yaşam kalitesinin kendisi tarafından belirlenen kriterlere göre değerlendirilmesi" olarak tanımlanır (Veenhoven, 1996: 17). Bilişsel ve yargılayıcı bir sürece işaret eden yaşam doyumunu (Diener vd., 1985: 71) Jan ve Masood (2008: 33) "bireyin bir bütün olarak yaşamına karş1 olumlu bir tutum sergilemesi" şeklinde tanımlamışlardır. Ayrıca, yaşam doyumunu açıklamak için "mutluluk" (Goldings, 1954: 31; Cummins, 1998: 308; Veenhoven, 1996: 17, 2000: 1) ve "öznel iyi olma" kavramlar1 da kullanılmaktadır (Veenhoven, 1996: 6, 2000: 1). Mutluluk; moral, cesaret vb. gibi değişik açılardan iyi olma halini tanımlar (Yılmaz vd., 2010: 93). Öznel iyi olma ise, genellikle bir kişinin yaşam doyumuna ilişkin değerlendirmesi olarak tanımlanır (Hybron, 2000: 221).

Yerli ve yabancı literatür incelendiğinde, yaşam doyumunu etkileyen başlıca faktörler arasında kişisel ve demografik (Diener vd., 2000: 426; Sousa and Lyubomirsky, 2001: 681; Siedlecki vd., 2008: 154; Avşaroğlu vd., 2005: 124; Stevenson and Wolfers, 2013: 598; Uslan, 2016: 3361), iş ile ilgili (Schmitt and Pulakos, 1985: 161; Uyguç vd., 1998: 193; Keser, 2005: 81; Çevik ve Korkmaz, 2014: 133), çevresel (Y1lmaz vd., 2010: 105; Dastmalchian vd., 1991; Lorenz, 1992; Akt. Özdevecioğlu, 2004: 214) ve toplumsal (Özdevecioğlu ve Aktaş, 
2007: 8; Dost, 2007: 140-141; Tümkaya vd., 2008: 2-3) faktörlerin yer aldığg görülmektedir. Appleton ve Song (2008: 2330-2334) yaşam doyumunun; (1) gelir, (2) meslek ve sosyal statü, (3) firsatlar ve sosyal hareketlilik, (4) refah durumu, (5) devlet politikası ve çevre, (6) aile ve sosyal ilişkiler olmak üzere altı bileşenden oluştuğunu belirtmişlerdir.

Yaşam doyumu, tüm yaş grupları gibi üniversite öğrencileri için de önem arz etmektedir. Üniversiteye başlayacak öğrencilerin çoğu, memleketlerinden farklı bir şehirde okula gitmelerinin getirdiği zorlukların (Özgür vd., 2010: 26) yanı sıra akademik çalışmaların ortaya çıkardığı zorlanmalar ve yeni arkadaşlar bulma ihtiyacı gibi durumlarla da karşı karşıya kalmaktadırlar (Matheny vd., 2002: 82). $\mathrm{Bu}$ durum öğrencilerin yeni bir yaşama alışmalarını gerektirmekte ve birçok gencin yaşamında önemli değişikliklere ve ruhsal problemlere neden olmaktadır (Özgür vd., 2010: 26).

\section{KAVRAMLAR ARASI İLIŞKİ VE HIPOTEZ GELISSTIIRME}

\section{Sosyal Zekâ ve Girișimcilik Niyeti İlișkisi}

Üniversite öğrencilerinin yüksek düzeyde sosyal zekâya sahip olmaları durumunda girişimcilik niyetlerinin bundan pozitif yönde etkileneceği düşünülmektedir. Sosyal zekâ ve girişimcilik niyeti değişkenleri arasındaki ilişkileri inceleyen önceki çalışmalara bakıldığında, olumlu yönlü ve farklı düzeylerde ilişkiler saptanmıştır. Aykol ve Yener (2009) 236 yeni üniversite mezunu üzerinde yaptığı araştırma ile sosyal zekâ ve sosyal bilgi süreci, sosyal beceriler ve sosyal farkındalık alt boyutları ile girişimcilik niyeti arasında pozitif ve anlamlı bir ilişki olduğunu bulmuşlardır.

Demirel vd. (2011) tarafından girişimci davranış ile çoklu zekâ alanları arasındaki ilişkiyi belirlemek amacıyla yapılan çalışmada, örneklem olarak 212 küçük ve orta ölçekli işletme (KOBİ) sahipleri seçilmiştir. Çalışma sonucunda sosyal zekânın girişimcilik üzerinde anlamlı ve olumlu etkileri olduğu belirlenmiştir.

Parlak (2013), İstanbul'da 448 lise son sınıf öğrencisi üzerinde yaptı̆̆ çalışmada, girişimci kişilik özellikleri ile içsel ve sosyal zekâ arasındaki ilişkiyi ölçmüş ve sonuç olarak olumlu ve anlamlı bir ilişki bulmuştur.

Kahya ve Ceylan (2017)'nın yapmış olduğu araştırmada, sosyal zekâ düzeyinin girişimcilik potansiyeli üzerindeki etkisine bakılmıştır. 305 üniversite öğrencisinden veri toplanan araştırmanın sonuçları, sosyal zekânın alt boyutları olan sosyal bilgi süreci, sosyal beceriler ve sosyal farkındalığın girişimcilik potansiyelini olumlu etkilediğini göstermiştir. 
Uzun vd. (2017) tarafindan meslek yüksekokul öğrencileri üzerinde yapılan araştırma kapsamında 249 adet anket verisi toplanmıştır. Araştırmanın sonuçlarına göre, sosyal zekânın empati ve manipülasyon boyutunun girişimcilik niyeti üzerinde etkisi olduğu tespit edilmiştir.

Pekkan ve Sisman (2020) tarafindan yapılan araştırmada, sosyal zekâ ile girişimcilik niyeti arasındaki ilişki ölçülmüştür. Araştırma, Uluslararası Koçluk Federasyonu (ICF) tarafından akredite edilmiş profesyonel koçluk sertifikasına sahip 175 katılımcı üzerinde yapılmıştır. Tromso Sosyal Zekâ Ölçeğinin (TSZÖ) kullanıldığ araştırmanın sonuçlarına göre; sosyal zekânın sosyal bilgi süreci ve sosyal beceriler alt boyutlarının girişimcilik niyeti ile pozitif ve anlamlı bir ilişki içinde olduğu, ancak sosyal farkındalık alt boyutu ile girişimcilik niyeti arasında ise istatistiksel olarak anlamlı bir ilişki tespit edilememiştir.

Sosyal zekâ ve girişimcilik niyeti arasındaki ilişkiyi ifade eden teorik ve ampirik literatür bilgilerinden hareketle bu araştırma için oluşturulan hipotezler aşağıda sunulmuştur;

$\mathbf{H}_{1}$ : Sosyal bilgi süreci, girişimcilik niyetini anlamlı ve pozitif yönde etkiler.

$\mathbf{H}_{2}$ : Sosyal farkındalık, girişimcilik niyetini anlamlı ve pozitif yönde etkiler.

\section{Sosyal Zekâ ve Yaşam Doyumu İlişkisi}

Sosyal zekâsı yüksek olan insanlar, gelecekte olmak istedikleri yere ulaşmak için ihtiyaç duydukları davranışları sergileme yeteneğine sahiptirler. Bu nedenle, yüksek sosyal zekâya sahip kişiler, yaşam doyumu ve mutluluk gibi pozitif duyguların yaratıcıları olabilir. Aminpoor (2013) tarafından yapılan araştırmada, kadın ve erkek üniversite öğrencileri arasında sosyal zekâ ve mutluluk arasındaki ilişkinin test edilmesi amaçlanmıştır. Araştırmanın örneklemi rastgele seçilen 226 öğrenciden oluşmuştur. Araştırmanın sonuçları, sosyal zekâ ve mutluluk arasında anlamlı ve pozitif yönlü bir ilişki olduğunu ortaya koymuştur.

Doğan ve Eryılmaz (2014) tarafından yapılan araştırmada, sosyal zekânın mutluluk üzerindeki etkisi incelenmiştir. Araştırmaya 130'u kadın, 119'u ise erkek olmak üzere toplamda 249 üniversite öğrencisi katılmıştır. Verilerin analizinde korelasyon ve çoklu regresyon analizi teknikleri kullanılan araştırma sonuçlarına göre, sosyal zekâ alt boyutlarının üniversite öğrencilerinin mutluluk düzeyleri ile pozitif ve istatistiksel olarak anlamlı düzeyde ilişkili olduğu belirlenmiştir.

Honarmand vd. (2014) yapmış oldukları araştırmada, yaşlı insanların yaşam doyumunda sosyal zekâ ve boyutlarının rolünü incelemeyi amaçlamışlardır. Araştırma verilerini elde edebilmek için 149 yaşı birey seçilmiştir. Araştırma 
sonucunda sosyal zekâ ve sosyal bilgi süreci, sosyal beceriler ve sosyal farkındalık alt boyutları ile yaşam doyumu arasında pozitif yönlü ve anlamlı ilişki tespit edilmiştir.

Khan ve Bhat (2017) tarafından yapılan araştırmada, sosyal zekânın pozitif ve negatif refah ile ilişkisinin test edilmesi amaçlanmıştır. Araştırmaya 50 kadın öğrenci katılmıştır. Araştırma sonucunda; sosyal zekânın sosyal bilgi süreci ve sosyal beceriler alt boyutları ile yaşam doyumu arasında pozitif yönlü anlamlı bir ilişki, sosyal farkındalık alt boyutu ile yaşam doyumu arasında ise istatistiksel olarak bir ilişki bulunamamıştır. Dehdashti Lesani vd. (2020)'nin yaptı̆̆ 1 araştırmada, sosyal zekânın mutluluk üzerinde olumlu yönlü ve anlamlı bir etkisinin olduğu tespit edilmiştir.

Bu bilgilere dayanarak oluşturulan hipotezler şu şekildedir;

$\mathbf{H}_{3}$ : Sosyal bilgi süreci yaşam doyumunu anlamlı ve pozitif yönde etkiler.

$\mathbf{H}_{4}$ : Sosyal farkındalık yaşam doyumunu anlamlı ve pozitif yönde etkiler.

$\mathrm{Bu}$ hipotezler doğrultusunda oluşturulan araştırma modeli aşağıda yer almaktadır:

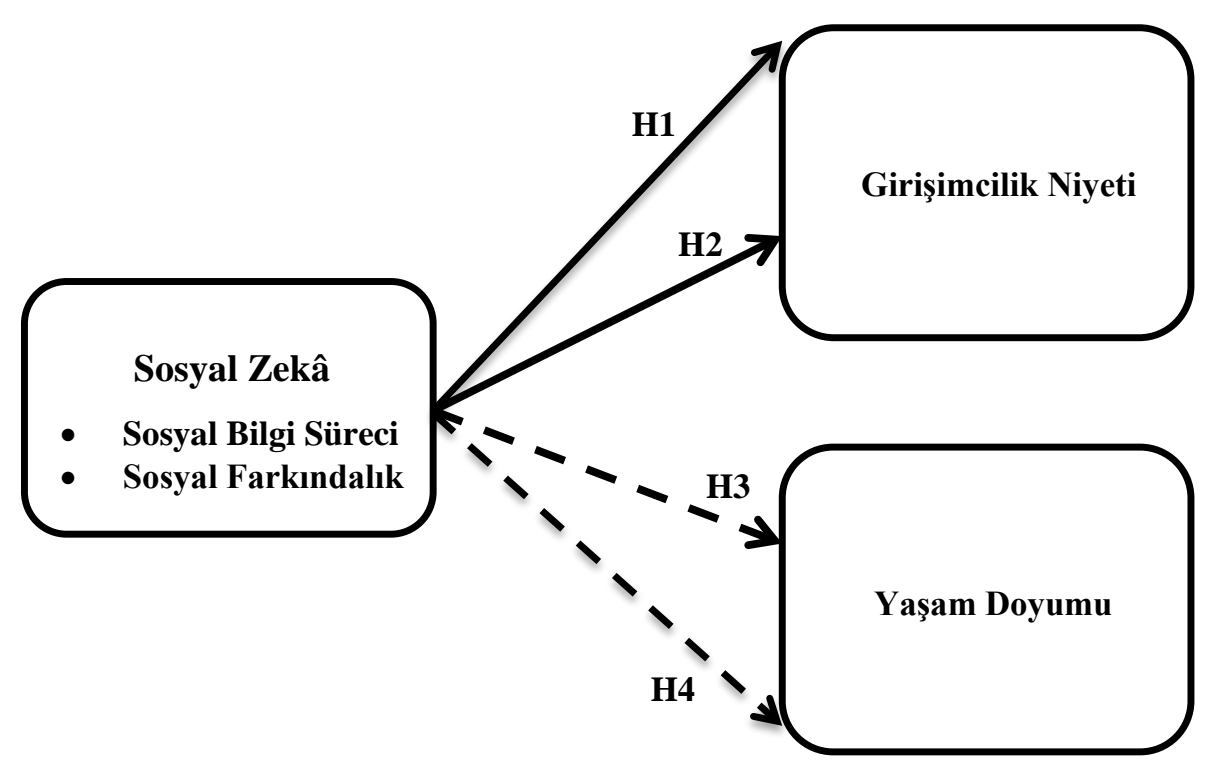

Şekil 1: Araştırmanın Modeli 


\section{YÖNTEM}

\section{Araştırmanın Yöntemi}

Alanyazına (Doğan ve Eryılmaz, 2014; Honarmand vd., 2014; Kahya ve Ceylan, 2017; Uzun vd., 2017; Khan and Bhat, 2017; Pekkan ve Sisman, 2020) dayanarak sosyal zeka, girişimcilik niyeti ve yaşam doyumu değişkenleri arasındaki ilişkinin ölçülmesi için nicel araştırma yöntemi uygulanmış ve araştırma verileri anket tekniği kullanılarak elde edilmiştir. Anket formunda üç grup ölçek yer almakta ve katılımcıların anlayabilmesi için ölçekleri oluşturan ifadeler orijinal dilden Türkçeye araştırmacılar tarafından çevrilmiştir. Yapılan çevirilerin uygunluğunun incelenmesi amaciyla alanında uzman akademisyenlerle paylaşılarak onların da görüşleri alınmış ve gerekli yerlerde revizyon işlemleri yapılarak çeviri işlemleri sonlandırılmışıtır. Bu gruplardaki ifadeler araştırmanın temel değişkenleri olan sosyal zekâ, girişimcilik niyeti ve yaşam doyumunu belirlemeye yöneliktir. Ölçeklerde yer alan her bir önerme, " $1=$ kesinlikle katılmıyorum, 5= kesinlikle katılıyorum" ifadelerinden oluşan 5'li Likert Tipi Ölçek ile değerlendirilmiştir.

Anket verilerinin analizinde SPSS programı kullanılmıştır. Yapılan analizler sırasıyla doğrulayıcı faktör analizi, güvenirlik analizi, korelasyon ve regresyon testidir.

\section{Evren ve Örneklem}

Araştırmanın evrenini Akdeniz Bölgesinde bir devlet üniversitesinde 20192020 öğretim yılında öğrenim görmekte olan son sinıf İ.İ.B.F öğrencileri oluşturmaktadır. Son sınıf İ.İ.B.F. öğrenci sayısının 993 olduğu öğrenilmiştir. Örneklem sayısını belirlemek için " $n=$ N.z2. $\sigma 2$ / (N-1). H2 + z2 . 62 " formülü kullanılmıştır (Ural ve Kılıç, 2013: 35-45). Bu formülde, N: evrenin büyüklügü; n: örneklem büyüklüğ̈̈; $\sigma$ : standart sapma değeri; $H$ : standart hata değeri; $Z$ : belirli bir $\alpha$ anlamlılı düzeyine karşılık gelen teorik değeri ifade etmektedir. \%95 güven aralığ $1(z=1,96), 0,05$ örnekleme hatası $(H), 0,5$ standart sapma $(\sigma)$ ile 993 evren büyüklüğü $(\mathrm{N})$ değerleri için araştırmada incelenmesi gereken örneklem sayısının 278 son sınıf İktisadi ve İdari Bilimler Fakültesinde öğrenim gören öğrenci olması gerektiği belirlenmiş̧ir. Basit tesadüfi örnekleme metoduyla ile seçilen 303 öğrenciye anket uygulanmıştır.

Araştırmada kullanılan anket formunun araştırmanın etik değerlerine uygun olduğunu gösteren "2020-35" sayıl1 etik kurulu karar1 24.11.2020 tarihinde Kahramanmaraş Sütçü İmam Üniversitesi Sosyal ve Beşerî Bilimler Etik Kurulundan alınmıştır. 


\section{Kullanılan Ölçekler}

Sosyal zekâ, girişimcilik niyeti ve yaşam doyumu için kullanılan ölçekler, alanyazın etraflıca tarandıktan sonra önceden yapılan araştırmalarda kullanılmış standart ve geçerliliği kanıtlanmış ölçeklerden oluşmaktadır.

\section{Tromso Sosyal Zekâ Ölçeği (TSZÖ)}

Anket formunun oluşturulmasında sosyal zekâyla ilgili sorular, Silvera vd. (2001)'nin geliştirdiği 21 soruluk ölçekten yararlanılarak hazırlanmıştır. Bu ölçeğe göre sosyal zekâ üç boyuttan oluşmaktadır; sosyal bilgi süreci (7 önerme), sosyal beceriler ( 7 önerme) ve sosyal farkındalık ( 7 önerme). "Diğer insanların davranışlarını önceden tahmin edebilirim", "Başkalarının isteklerini anlarım", "İnsanlarla ilk tanışmada ve yeni ortamlara girme konusunda iyiyimdir", "Yeni insanlarla iyi ilişkiler kurmakta başarılıyımdır", "İnsanlar açıklama yapmama izin verirler, açıklamam için bana kızmazlar", "Diğer insanların yaptıklarıma verdikleri tepkiler beni şaşırtmaz" gibi önermeler Tromso sosyal zekâ ölçeğinde ifade edilen önermeler arasındadır.

\section{Girişimcilik Niyeti Ölçeği}

Girişimcilik niyeti değişkeni, Linan ve Chen (2009) tarafından geliştirilen tek alt boyutlu ölçek kullanılarak ölçümlenmiştir. Ölçek 6 önermeden oluşmaktadır. "Gelecekte bir firma kurmaya kararlıyım", "Kendi firmamı kurmak ve işletmek için her türlü çabayı gösteririm" gibi önermeler girişimcilik niyeti ölçeğinde yer alan önermelerden bazılarıdır.

\section{Yaşam Doyumu Ölçeği}

Yaşam doyumu için Diener vd. (1985) tarafindan geliştirilen tek alt boyutlu ölçek kullanılmıştır. Yaşam doyumu ölçeği 5 önermeden oluşmaktadır. "Şimdiye kadar hayatta istediğim önemli şeyleri aldım", "Yaşamımdan memnunum" gibi önermeler yaşam doyumu ölçeğinde ifade edilen önermeler arasındadır.

\section{Araştırmanın Bulguları}

\section{Demografik Özellikler}

Tablo 2'de görüldüğü gibi; araştırmada yer alan öğrencilerin \%37'si kadın iken, \%63'ü erkeklerden oluşmaktadır. Araştırmaya katılan öğrencilerin \%0,7'si 20 yaş ve altında iken, \%94,7'si $21-25$ yaş arasında ve \%4,6's1 26-30 yaş gruplarında yer almaktadır. Öğrencilerin \%4,0'ü evli, \%94,3'ü bekâr ve \%1,7'si diğer grubunda yer almaktadır. "Girişimcilik dersi aldınız mı?" sorusuna katılımcıların \%51,2'si evet, \%48,8'i hayır cevab1 vermişlerdir. Araştırma açısından önemli olan bu ifadeye verilen yanıtlarda dengeli bir dağılımın 
olduğunu söylemek mümkündür. Eğitim aldıkları bölüm açısından ise katılımc1ların \%26,7'sinin İktisat bölümünden, \%26,4'ünün İşletme bölümünden, \%14,5'inin Siyaset Bilimi ve Uluslararası İlişkiler bölümünden, \%14,2'sinin Kamu Yönetimi bölümünden, \%18,2'sinin ise Sağlık Yönetimi bölümünden oldukları anlaşılmaktadır. Katılımcıların not ortalamaları incelendiğinde; \%20,1'inin not ortalamas1 1.50-2.00, \%31,7'sinin 2.01-2.50, \%30,0'unun 2.51-3.00, \%14,9'unun 3.01-3.50, \%3,3'nün ise 3.51-4.00 aralığında olduğu görülmektedir.

Tablo 2. Demografik Özellikler

\begin{tabular}{|c|c|c|c|}
\hline Değişken & Özellik & Kişi & Yüzde \\
\hline \multirow[t]{3}{*}{ "Cinsiyet } & Kadın & 112 & \%37,0 \\
\hline & Erkek & 191 & $\% 63,0$ \\
\hline & Toplam & 303 & $\% 100,0$ \\
\hline \multirow[t]{5}{*}{ Yaşınız } & 20 ve Altı & 2 & $\% 0,7$ \\
\hline & $21-25$ & 287 & $\% 94,7$ \\
\hline & $26-30$ & 14 & $\% 4,6$ \\
\hline & 31 ve Üstü & - & - \\
\hline & Toplam & 303 & $\% 100,0$ \\
\hline \multirow{4}{*}{ Medeni Durum } & Evli & 12 & $\% 4,0$ \\
\hline & Bekâr & 286 & $\% 94,3$ \\
\hline & Diğer & 5 & $\% 1,7$ \\
\hline & Toplam & 303 & $\% 100,0$ \\
\hline \multirow{3}{*}{$\begin{array}{l}\text { Girişimcilik Dersi } \\
\text { Alma }\end{array}$} & Evet & 155 & $\% 51,2$ \\
\hline & Hayır & 148 & $\% 48,8$ \\
\hline & Toplam & 303 & $\% 100,0$ \\
\hline \multirow[t]{6}{*}{ Not Ortalaması } & $1.50-2.00$ & 6161 & $\% 20,1$ \\
\hline & $2.01-2.50$ & 96 & $\% 31,7$ \\
\hline & $2.51-3.00$ & 91 & $\% 30,0$ \\
\hline & $3.01-3.50$ & 45 & $\% 14,9$ \\
\hline & $3.51-4.00$ & 10 & $\% 3,3$ \\
\hline & Toplam & 303 & $\% 100,0$ \\
\hline \multirow[t]{6}{*}{ Bölüm } & İktisat & 81 & $\% 26,7$ \\
\hline & İşletme & 80 & $\% 26,4$ \\
\hline & $\begin{array}{l}\text { Siyaset Bilimi ve } \\
\text { Uluslararası İlişkiler }\end{array}$ & 44 & $\% 14,5$ \\
\hline & Kamu Yönetimi & 43 & $\% 14,2$ \\
\hline & Sağlık Yönetimi & 55 & $\% 18,2$ \\
\hline & Toplam & 303 & $\% 100,0$ \\
\hline
\end{tabular}




\section{Faktör Analizi Sonuçları}

Araştırmada kullanılan TROMSO sosyal zekâ ölçeğinin KMO değeri 0,815; Bartlett's Küresellik Testi sonucunda ise Ki-kare 907,720, serbestlik derecesi değeri (df) 91 ve anlamlılık değeri (sig) 0,000 olarak bulunmuştur. Bu bilgiler doğrultusunda ölçeğin faktör analizi için uygun olduğu görülmüsstür. Tablo 3 sosyal zekâ ölçeğinin faktör analizi sonuçlarını içermektedir. TROMSO Sosyal Zekâ Ölçeğinin orijinali Silvera vd. (2001) tarafından üç boyutlu (1. sosyal bilgi süreci, 2. sosyal beceriler ve 3. sosyal farkındalık) olarak ele alınırken, bu araştırmada yapılan faktör analizi sonucunda, sosyal beceriler alt boyutuna ait maddelerin (s.z4, s.z7, s.z10, s.z12, s.z15, s.z18, s.z20) normal dağılım sağlamadığ 1 görülmüștür. $\mathrm{Bu}$ nedenle, çalışmaya sosyal beceriler alt boyutu çıkarılarak devam edilmiştir.

Tablo 3. TROMSO Sosyal Zekâ Ölçeğine İlişkin Faktör Değerleri

\begin{tabular}{|c|c|c|c|c|}
\hline \multicolumn{5}{|c|}{ KMO ve Bartlett's Test } \\
\hline \multicolumn{3}{|c|}{ Kaiser-Meyer-Olkin örnekleme yeterliliği ölçüsü } & \multicolumn{2}{|c|}{0,815} \\
\hline \multirow{3}{*}{\multicolumn{2}{|c|}{ Bartlett’s küresellik testi }} & Ki-kare & \multicolumn{2}{|c|}{907,720} \\
\hline & & $\mathrm{Sd}$ & \multicolumn{2}{|c|}{91} \\
\hline & & Anlamlılik & \multicolumn{2}{|c|}{,000 } \\
\hline \multicolumn{3}{|c|}{ Açıklanan toplam varyans } & \multicolumn{2}{|c|}{59,470} \\
\hline Boyut & \multicolumn{2}{|r|}{ Madde } & \multicolumn{2}{|c|}{ Faktör Yükü } \\
\hline \multirow{7}{*}{$\begin{array}{l}\text { Sosyal } \\
\text { Bilgi } \\
\text { Süreci }\end{array}$} & \multicolumn{2}{|c|}{$\begin{array}{l}\text { s.z1: Diğer insanların davranışlarını önceden tahmin } \\
\text { edebilirim }\end{array}$} & ,702 & \\
\hline & \multicolumn{2}{|c|}{$\begin{array}{l}\text { s.z17: Diğer insanların davranışlarıma nasıl tepki } \\
\text { vereceğini tahmin edebilirim }\end{array}$} & ,674 & \\
\hline & \multicolumn{2}{|c|}{$\begin{array}{l}\text { s.z3: Davranışlarımın diğer insanlara ne hissettirdiğini } \\
\text { bilirim }\end{array}$} & ,668 & \\
\hline & \multicolumn{2}{|c|}{ s.z9: Başkalarının isteklerini anlarım } & ,638 & \\
\hline & \multicolumn{2}{|c|}{ s.z6: Diğer insanların duygularını anlayabilirim } & ,632 & \\
\hline & \multicolumn{2}{|c|}{$\begin{array}{l}\text { s.z14: Bir açıklama yapmalarına gerek kalmadan } \\
\text { insanların ne yapmaya çalıştıklarını çoğunlukla } \\
\text { anlarım }\end{array}$} & ,630 & \\
\hline & \multicolumn{2}{|c|}{$\begin{array}{l}\text { s.z19: Diğer insanların yüz ifadelerinden, beden } \\
\text { dillerinden vs. gerçekte ne demek istediklerini } \\
\text { çoğunlukla anlarım }\end{array}$} & ,563 & \\
\hline \multirow[t]{3}{*}{$\begin{array}{l}\text { Sosyal } \\
\text { Farkındalık }\end{array}$} & \multicolumn{2}{|c|}{$\begin{array}{l}\text { s.z11: Ne düşündüğümü söylediğimde insanlar } \\
\text { çoğunlukla bana kıgıın ya da bana sinirlenmiş gibi } \\
\text { gelmiyor }\end{array}$} & & ,674 \\
\hline & \multicolumn{2}{|c|}{$\begin{array}{l}\text { S.z8: İnsanlar açıklama yapmama izin verirler, } \\
\text { açıklamam için bana kızmazlar. }\end{array}$} & & 635 \\
\hline & \multicolumn{2}{|c|}{ s.z16: Farkında olmadan sık sık başkalarını incitmem } & & ,628 \\
\hline
\end{tabular}




\begin{tabular}{|l|l|c|}
\hline & $\begin{array}{l}\text { S.z21: Diğer insanların yaptıklarıma verdikleri } \\
\text { tepkiler beni şaşırtmaz }\end{array}$ &, 621 \\
\cline { 2 - 3 } & S.z13: İnsanları tahmin edilebilir bulurum &, 586 \\
\cline { 2 - 3 } & s.z5: İnsanlar yaptıkları şeylerle beni şaşırtmazlar &, 458 \\
\hline & $\begin{array}{l}\text { s.z2: Çoğunlukla başkalarının tercihlerini anlamanını } \\
\text { kolay olduğunu hissederim }\end{array}$ &, 369 \\
\hline
\end{tabular}

*s.z=sosyal zekâ

Girişimcilik niyeti ölçeğinin KMO değeri 0,869 olarak belirlenmiştir. Ayrıca Bartlett's Küresellik Testi sonucunda ise Ki-kare değeri 1175,840, serbestlik derecesi değeri (df) 15 ve anlamlılık değeri (sig) 0,000 olarak saptanmıştır. Bu veriler doğrultusunda ölçeğin faktör analizine uygun olduğu tespit edilmiştir. Açıklanan toplam varyans değeri \%68,138 olarak belirlenen ölçeğin faktör analizi sonuçları Tablo 4'de yer almaktadır. Faktör yüklenme değerleri ise 0,897 ile 0,581 arasında yer alan ölçeğin araştırmada kullanılması için uygun olduğu görülmüştür.

Tablo 4. Girişimcilik Niyeti Ölçeğine İlişkin Faktör Değerleri

\begin{tabular}{|c|c|c|c|}
\hline \multicolumn{4}{|c|}{ KMO ve Bartlett's Test } \\
\hline \multicolumn{3}{|c|}{ Kaiser-Meyer-Olkin örnekleme yeterliliği ölçüsü } & 0,869 \\
\hline \multirow{3}{*}{\multicolumn{2}{|c|}{ Bartlett’s küresellik testi }} & Ki-kare & 1175,840 \\
\hline & & Sd & 15 \\
\hline & & Anlamlilık & ,000 \\
\hline \multicolumn{3}{|c|}{ Açıklanan toplam varyans } & 68,138 \\
\hline Boyut & \multicolumn{2}{|c|}{ Madde } & $\begin{array}{l}\text { Faktör } \\
\text { Yükü }\end{array}$ \\
\hline \multirow{6}{*}{$\begin{array}{l}\text { Girişimcilik } \\
\text { Niyeti }\end{array}$} & \multicolumn{2}{|c|}{ " g.n4: Gelecekte bir firma kurmaya kararlıyım } & ,897 \\
\hline & \multicolumn{2}{|c|}{ g.n5: Bir firma kurmayı ciddi anlamda düşünüyorum } & ,883 \\
\hline & \multicolumn{2}{|c|}{ g.n6: Bir gün bir firma kurmaya niyetim var } & 829 \\
\hline & \multicolumn{2}{|c|}{$\begin{array}{l}\text { g.n3: Kendi firmamı kurmak ve işletmek için her } \\
\text { türlü çabayı gösteririm }\end{array}$} & ,786 \\
\hline & \multicolumn{2}{|c|}{ g.n2: Benim mesleki hedefim girişimci olmak } & ,691 \\
\hline & \multicolumn{2}{|c|}{ g.n1: Girişimci olmak için her şeyi yapmaya hazırım } &, 581 \\
\hline
\end{tabular}

*g.n=girişimcilik niyeti

Tablo 5. Yaşam Doyumu Ölçeğine İlişkin Faktör Değerleri

\begin{tabular}{|c|c|c|}
\hline \hline \multicolumn{2}{|c|}{ KMO ve Bartlett's Test } \\
\hline \hline Kaiser-Meyer-Olkin örnekleme yeterliliği ölçüsü & 0,811 \\
\hline \multirow{3}{*}{ Bartlett's küresellik testi } & Ki-kare & 443,910 \\
\cline { 2 - 3 } & Sd & 10 \\
\cline { 2 - 3 } & Anlamlılık &, 000 \\
\hline
\end{tabular}




\begin{tabular}{|c|c|c|}
\hline \multicolumn{2}{|r|}{ Açıklanan toplam varyans } & \multirow{2}{*}{$\begin{array}{c}57,045 \\
\text { Faktör } \\
\text { Yükü } \\
\end{array}$} \\
\hline Boyut & Madde & \\
\hline \multirow[t]{5}{*}{$\begin{array}{l}\text { Yaşam } \\
\text { Doyumu }\end{array}$} & $\begin{array}{l}\text { y.d4: Şimdiye kadar hayatta istediğim önemli şeyleri } \\
\text { aldım }\end{array}$ & ,783 \\
\hline & y.d3: Yaşamımdan memnunum & ,714 \\
\hline & y.d2: Yaşam koşullarım mükemmeldir & ,708 \\
\hline & $\begin{array}{l}\text { y.d5: Hayatımı tekrar yaşama şansım olsaydı, } \\
\text { neredeyse hiçbir şeyi değiștirmezdim }\end{array}$ & ,616 \\
\hline & y.d1: Pek çok açıdan idealime yakın yaşamım var & ,581 \\
\hline
\end{tabular}

*y.d=yaşam doyumu

Yaşam doyumu ölçeğinin KMO değeri 0,811 olup faktör analizi için örneklem büyüklüğü yeterli düzeydedir. Bartlett's Küresellik Testi sonucunda Ki-kare değeri 443,910, serbestlik derecesi değeri (df) 10 ve anlamlılık değeri (sig) 0,000 olarak belirlenmiştir. Yaşam doyumu ölçeğinin faktör analizi sonuçları Tablo 5 'de verilmiştir. Yaşam doyumu ölçeğinin faktör yüklenme değerleri 0,783 ile 0,581 arasında yer almıştır. $\mathrm{Bu}$ verilerden hareketle, ölçeğin araştırmada kullanılmak için uygun ölçek olduğu sonucuna ulaşılmıştır.

\section{Güvenilirlik Analizi Sonuçları}

Güvenirlik analizi sonuçları ile ilgili bulgular Tablo 6'da gösterilmektedir. Araştırmada yer alan ölçeklerin güvenirlik değerlerinin belirlenmesi için Cronbach's Alpha katsayısı kullanılmaktadır. Sınır değerlerin belirlenmesinde Nunally (1978) ve Hair vd. (2014) tarafindan belirtilen 0,70 değeri esas alınmıştır. Araştırmada kullanılan ölçeklerin güvenilirlik analizi sonucunda Cronbach's Alpha değerleri; sosyal zekâ ölçeğinin sosyal bilgi süreci alt boyutunun 0,814, bir diğer sosyal zekâ alt boyutu olan sosyal farkındalığın 0,743, girişimcilik niyeti ölçeğinin 0,905 ve yaşam doyumu ölçeğinin 0,807 olarak belirlenmiştir. Sonuç olarak, ölçeklerin Cronbach's Alpha değerleri Nunally (1978) ve Hair vd. (2014) tarafından belirtilen 0,70 yeterlik düzeyinin üzerinde olduğu görülmüş ve ölçekler güvenilir olarak kabul edilmiştir.

Tablo 6. Güvenirlik Katsayıları

\begin{tabular}{|l|c|c|}
\hline \hline Değişkenler & Madde Sayısı & $\begin{array}{c}\text { Cronbach Alfa } \\
\text { Değeri }\end{array}$ \\
\hline \hline Sosyal Bilgi Süreci & 7 & 0,814 \\
\hline Sosyal Farkındalık & 7 & 0,743 \\
\hline Girişimcilik Niyeti & 6 & 0,905 \\
\hline Yaşam Doyumu & 5 & 0,807 \\
\hline \hline
\end{tabular}




\section{Korelasyon ve Regresyon Analizi Sonuçları}

Araştırmanın bağımsız (sosyal zekâ boyutları) ve bağımlı değişkenleri (girişimcilik niyeti ve yaşam doyumu) arasında istatistiksel olarak anlamlı bir ilişki olup olmadığını tespit etmek amacıyla korelasyon analizi yapılmıştır. $\mathrm{Bu}$ analizin sonuçları Tablo 7'de görülmektedir. Korelasyon analizi sonucunda sosyal bilgi süreci boyutu ile girişimcilik niyeti arasında zayıf düzeyde $(\mathrm{r}=0,213)$, pozitif yönlü ve istatistiksel olarak anlamlı bir ilişki bulunmuştur $(\mathrm{p}=0,000)$. Sosyal bilgi süreci boyutu ile yaşam doyumu arasında zayıf düzeyde $(\mathrm{r}=0,229)$, pozitif yönlü ve istatistiksel olarak anlamlı bir ilişki bulunmuştur $(p=0,000)$. Sosyal farkındalık boyutu ile girişimcilik niyeti ve yaşam doyumu arasında istatistiksel olarak anlamlı bir ilişki tespit edilememiş bu nedenle araştırmanın ikinci (H2) ve dördüncü (H4) hipotezleri ret edilmiştir.

Tablo 7. Değişkenler Arasındaki İlişkiler

\begin{tabular}{|c|c|c|c|c|}
\hline \multicolumn{2}{|l|}{ Değişkenler } & 1 & 2 & 3 \\
\hline \multirow{2}{*}{$\begin{array}{l}\text { 1. Sosyal Bilgi } \\
\text { Süreci }\end{array}$} & Pearson Korelasyon & 1 & & \\
\hline & $\mathrm{P}$ değeri & & & \\
\hline \multirow{2}{*}{$\begin{array}{l}\text { 2. Sosyal } \\
\text { Farkındalık }\end{array}$} & Pearson Korelasyon & 0,099 & 1 & \\
\hline & P değeri & 0,084 & & \\
\hline \multirow{2}{*}{$\begin{array}{l}\text { 3. Girişimcilik } \\
\text { Niyeti }\end{array}$} & Pearson Korelasyon & $0,213 * *$ & 0,107 & 1 \\
\hline & P değeri & 0,000 & 0,062 & \\
\hline \multirow{2}{*}{$\begin{array}{l}\text { 4. Yaşam } \\
\text { Doyumu }\end{array}$} & Pearson Korelasyon & $0,229 * *$ & 0,057 & $0,261^{* *}$ \\
\hline & $\mathrm{P}$ değeri & 0,000 & 0,325 & 0,000 \\
\hline
\end{tabular}

Tablo 8'de öğrencilerin sosyal zekâ alt boyutlarından sosyal bilgi süreci algılarının girişimcilik niyeti algıları üzerindeki etkisini gösteren regresyon analizi görülmektedir. Bağımlı değişkendeki (girişimcilik niyeti) değişimin bağımsız değişkenler (sosyal bilgi süreci) tarafından ne düzeyde açıklandığını ortaya koyan bir değer olan $\mathrm{R}^{2}$ bu analizde 0,046 olarak tespit edilmiştir. $\mathrm{Bu}$ bağlamda öğrencilerin sosyal bilgi süreci düzeyleri onların girişimcilik niyeti algılarının \%4,6'sını açıklayabilmektedir. Ayrıca değer olumlu yönlü ve istatistiksel olarak anlamlıdır. Regresyon analizi sonucunda " $\mathrm{H}_{1}$ : Sosyal bilgi süreci girişimcilik niyetini anlamlı ve pozitif yönde etkiler" hipotezi kabul edilmiştir. 
Tablo 8. Araştırmaya Katılan Öğrencilerin Sosyal Bilgi Süreci-Girişimcilik Niyeti Algısı İlişkisini Gösteren Regresyon Analizi Sonuçları

\begin{tabular}{|c|c|c|c|c|c|c|}
\hline \hline B & $\mathbf{R}$ & R Square & $\begin{array}{c}\text { Adjusted R } \\
\text { Square }\end{array}$ & F & P & t \\
\hline \hline 0,282 & 0,213 & 0,046 & 0,042 & 14,313 & $0,000^{* *}$ & 3,783 \\
\hline Bağımsız Değişken: Sosyal Bilgi Süreci \\
Bağımlı Değişken: Girişimcilik Niyeti \\
\hline
\end{tabular}

Yine öğrencilerin sosyal bilgi süreci alt boyutu düzeylerinin yaşam doyumu algısını açıklama derecesine ait sonuçlar Tablo 9'da görülmektedir. Sosyal bilgi sürecinin yaşam doyumunu açıklama düzeyi $\left(\mathrm{R}^{2}=0,052\right) \% 5,2$ olarak bulunmuştur. Tablodaki değere göre ortaya çıkan ilişki pozitif ve anlamlıdır. Regresyon analizi sonucunda " $\mathrm{H}_{3}$ : Sosyal bilgi süreci yaşam doyumunu anlamlı ve pozitif yönde etkiler” hipotezi kabul edilmiştir.

Tablo 9. Araştırmaya Katılan Öğrencilerin Sosyal Bilgi Süreci-Yaşam Doyumu Algısı İliş̧kisini Gösteren Regresyon Analizi Sonuçları

\begin{tabular}{|c|c|c|c|c|c|c|}
\hline \hline B & R & R Square & $\begin{array}{c}\text { Adjusted R } \\
\text { Square }\end{array}$ & F & P & t \\
\hline \hline 0,275 & 0,229 & 0,052 & 0,049 & 16,560 & $0,000^{* *}$ & 4,069 \\
\hline Bağımsız Değişken: Sosyal Bilgi Süreci \\
Bağımlı Değişken: Yaşam Doyumu \\
\hline
\end{tabular}

\section{SONUÇ, TARTIŞMA VE ÖNERILER}

$\mathrm{Bu}$ çalışmada, üniversitede eğitim gören öğrencilerin sosyal zekâ algıları ile girişimcilik niyeti ve yaşam doyumu arasındaki ilişki ortaya çıkartılmaya çalışılmıştır. Çalışmada, Akdeniz Bölgesinde bir devlet üniversitesinde son sınıf İİB öğrencilerinin sosyal zekâ düzeyleri algılarının girişimcilik niyetleri ve yaşam doyumları üzerindeki etkileri ölçülmeye çalışılmıştır.

Araştırmada yer alan ölçüm araçlarının yüksek düzeyde güvenilir olduğu tespit edilmiştir. Araştırmada kullanılan değişkenler arasındaki ilişkiler incelendiğinde; sosyal zekânın sosyal bilgi süreci alt boyutu ile girişimcilik niyeti ve yaşam doyumu arasında zayıf düzeyde, pozitif yönlü ve anlamlı bir ilişki olduğu, sosyal zekânın sosyal farkındalık alt boyutu ile girişimcilik niyeti ve yaşam doyumu arasında ise istatistiksel olarak anlamlı bir ilişki olmadığ 
görülmüştür. Sosyal bilgi süreci ile girişimcilik niyeti arasında pozitif ve anlamlı bir ilişkinin olması Aykol ve Yener (2009), Kahya ve Ceylan (2017) ve Pekkan ve Sisman (2020) tarafından yapılan çalışmaların sonuçları ile uyumludur. Yine sosyal bilgi süreci alt boyutu ile yaşam doyumu arasında tespit edilen pozitif ve anlamlı ilişki Honarmand vd. (2014), Doğan ve Eryılmaz (2014) ve Khan ve Bhat (2017) tarafından yapılan çalışmaların sonuçları ile desteklenmektedir. Öğrencilerin sosyal açıdan farkındalık algılarının girişimcilik niyetlerinde herhangi bir değişiklik ortaya koymaması ile ilgili sonuç Pekkan ve Sisman (2020) tarafından yapılan çalışmada elde edilen sonuçlarla benzerlik göstermektedir. Öğrencilerin sosyal farkındalık algılarının yaşam doyumları ile bir ilişkiye sahip olmadığını gösteren sonuç ise Khan ve Bhat (2017) tarafından yapılan çalışma sonuçları ile desteklenmektedir.

Girişimcilik niyetinin sosyal zekânın bir alt boyutu olan sosyal bilgi süreci tarafından ne düzeyde açıklanabildiğini belirlemek amacıyla yapılan regresyon analizi sonucunda, sosyal bilgi sürecinin girişimcilik niyetini açıklama düzeyinin $\% 4,6$ olduğu görülmüştür. Sosyal farkındalık alt boyutu ile girişimcilik niyeti arasında ise istatistiksel olarak anlamlı bir ilişki tespit edilemediğinden ilgili araştırma hipotezi $(\mathrm{H} 2)$ ret edilmiştir. Yaşam doyumunun sosyal bilgi süreci açısından ne düzeyde açılanabildiğini belirlemek amacıyla yapılan regresyon analizi sonucunda ise sosyal bilgi sürecinin yaşam doyumunu açıklama düzeyi $\% 5,2$ olarak tespit edilmiştir. Yine sosyal farkındalık alt boyutu ile yaşam doyumu arasında istatistiksel olarak anlamlı bir ilişki bulunamadığından araştırmanın ilgili hipotezi $(\mathrm{H} 4)$ ret edilmiştir.

Öğrencilerin sosyal bilgi süreci ve sosyal farkındalık düzeylerinin, girişimcilik niyeti ve yaşam doyumu algıları üzerindeki etkisini ortaya koymak amacıyla kurulan 4 araştırma hipotezinin kabul ve ret durumları ile araştırma bulgularının önceki araştırma bulgularıyla karşılaştırılması Tablo 10'da özetlenmiştir.

Tablo 10. Hipotezlerin Test Edilmesi Amaciyla Yapılan Korelasyon ve Regresyon Analizlerine İlişkin Sonuçlar ve Benzer Çalışma Sonuçları

\begin{tabular}{|c|l|c|l|}
\hline \hline \multicolumn{1}{|c|}{ Hipotezler } & Sonuç & Benzer Çalışma Sonuçları \\
\hline \hline $\mathbf{1}$ & $\begin{array}{l}\text { Sosyal bilgi süreci girişimcilik } \\
\text { niyetini anlamlı ve pozitif yönde } \\
\text { etkiler }\end{array}$ & Kabul & $\begin{array}{l}\text { (+) Aykol ve Yener (2009) } \\
(+) \text { Kahya ve Ceylan (2017) } \\
(+) \text { Pekkan ve Sisman (2020) }\end{array}$ \\
\hline $\mathbf{2}$ & $\begin{array}{l}\text { Sosyal farkındalık girişimcilik } \\
\text { niyetini anlamlı ve pozitif yönde } \\
\text { etkiler }\end{array}$ & Red & $\begin{array}{l}\text { (-) Aykol ve Yener (2009) } \\
(-) \text { Kahya ve Ceylan (2017) } \\
(+) \text { Pekkan ve Sisman (2020) }\end{array}$ \\
\hline
\end{tabular}




\begin{tabular}{|c|l|c|l|}
\hline 3 & $\begin{array}{l}\text { Sosyal bilgi süreci yaşam } \\
\text { doyumunu anlamlı ve pozitif } \\
\text { yönde etkiler }\end{array}$ & Kabul & $\begin{array}{l}\mathbf{( + ) ~ H o n a r m a n d ~ v d . , ~ ( 2 0 1 4 ) ~} \\
\mathbf{( + )} \text { Doğan ve Eryılmaz (2014) } \\
(+) \text { Khan ve Bhat }(2017)\end{array}$ \\
\hline 4 & $\begin{array}{l}\text { Sosyal farkındalık yaşam } \\
\text { doyumunu anlamlı ve pozitif } \\
\text { yönde etkiler }\end{array}$ & Red & $\begin{array}{l}\text { (-) Honarmand vd., (2014) } \\
(-) \text { Doğan ve Eryılmaz (2014) } \\
(+) \text { Khan ve Bhat (2017) }\end{array}$ \\
\hline \hline
\end{tabular}

Araştırma sonucunda ortaya çıkarılan bulgulara göre sosyal zekâ alt boyutlarından sosyal bilgi süreci girişimcilik niyetini ve yaşam doyumunu olumlu yönde etkilemektedir. Sonuç olarak, sosyal bilgi sürecine sahip öğrencilerin daha fazla girişimcilik niyetine ve daha yüksek yaşam doyumuna sahip olduğu söylenebilir. Sosyal farkındalık algı düzeyinin öğrencilerin girişimcilik niyetleri ve yaşam doyumları ile anlamlı bir ilişki içerisinde bulunmadığını gösteren araştırma bulgusu ise tartışmaya açık bir bulgudur. Normalde sosyal farkındalığı yüksek bireylerin girişimcilik niyetlerinin ve yaşam doyumlarının da yüksek olması beklenir. Bu bağlamda, bu araştırma sonucu sorgulayan yeni araştırmaların yapılması önerilmektedir.

Bu çalışmanın en büyük kısıtı, yalnızca bir üniversite öğrencilerinden veri toplanıp farklı üniversitelerin öğrencilerinden veri toplanmadığından bulguların genellenememesidir. Araştırmada yer alan öğrenciler Akdeniz Bölgesinde bir devlet üniversitesinde eğitim görmektedir. Türkiye'de eğitim veren diğer üniversitelerdeki veya sosyo-kültürel ve demografik açıdan farklılık gösteren ülkelerdeki öğrenciler farklı algılara sahip olabilir. $\mathrm{Bu}$ durum araştırma sonuçlarını etkileyebilir. Bu nedenle gelecekte yapılacak diğer araştırmalarda, yurtdışında ve Türkiye' de eğitim veren farklı üniversite öğrencilerinin örnekleme dahil edilmesi araştırma sonuçlarının genelleştirilebilmesi açısından önerilmektedir.

Bir başka konu ise araştırmaya katılan öğrencilerin eğitim gördügü bölüm ve sınıfının araştırmada önemli olduğudur. Bu bağlamda araştırmanın son sınıf İ̈BF öğrencileri üzerinde yapılması ayrıca bir kısıt oluşturmaktadır. Bu nedenle üniversitelerin farklı bölümlerinde eğitim gören öğrencileri örneklem alarak bir araştırmanın yapılması da tavsiye edilmektedir.

\section{KAYNAKÇA}

Akandere, M., Meryem, A. ve Baştuğ, G. (2009). Zihinsel ve fiziksel engelli çocuğa sahip anne ve babaların yaşam doyumu ve umutsuzluk düzeylerinin incelenmesi. Selçuk Üniversitesi Sosyal Bilimler Enstitüsü Dergisi, (22), 23-32. 
Aminpoor, H. (2013). Relationship between social intelligence and happiness in Payame Noor University students. Annals of Biological Research, 4(5), 165-168.

Appleton, S. and Song, L. (2008). Life satisfaction in urban China: Components and determinants. World Development, 36(11), 2325-2340.

https://doi.org/10.1016/j.worlddev.2008.04.009

Avşaroğlu, S., Deniz, M. E. ve Kahraman, A. (2005). Teknik öğretmenlerde yaşam doyumu iş doyumu ve mesleki tükenmişlik düzeylerinin incelenmesi. Selçuk Üniversitesi Sosyal Bilimler Enstitüsü Dergisi, (14), 115-129.

Aykol, S. ve Yener, M. (2009, September 10-11). The Impact of Social Intelligence and Sense of Humor on Entrepreneurial Intention: Evidence from Turkey [Paper presentation]. In Proceedings of the 4th European Conference on Entrepreneurship and Innovation: ECIE, Belgium. https://academic-conferences.org/2-proceedings.htm

Bakan, İ. ve Güler, B. (2017). Duygusal zekânın, yaşam doyumu ve akademik başarıya etkileri ve demografik özellikler bağlamında alg1 farklılıkları. Karamanoğlu Mehmetbey Üniversitesi Sosyal ve Ekonomik Araştırmalar Dergisi, 19(33), 1-11. https://doi.org/10.18493/kmusekad.399210

Bakan, İ., Ergün, K. ve Güler, B. (2017). Örgütsel demokrasi algısının çalışanların iç girişimcilik performansına etkileri: Marmaris’teki otel işletmelerinde bir alan araştırması. Hak Işs Uluslararası Emek ve Toplum Dergisi, 6(14), 115-138.

Balaban, Ö., ve Özdemir, Y. (2008). Girişimcilik eğitiminin girişimcilik eğilimi üzerindeki etkisi: Sakarya üniversitesi İ̈BF örneği. Girişimcilik ve Kalkınma Dergisi, 3(2), 133-147.

Bar-On, R. (2006). The Bar-On model of emotional-social intelligence (ESI) 1. Psicothema, 13-25.

Barutçu, E. ve İrmiş, A. (2012). Öğrencilerin kendilerini girişimci bir kişiliğe sahip görmelerini ve iş kurma niyetlerini etkileyen faktörler: bir alan araştırmas1. Atatürk Üniversitesi İktisadi ve İdari Bilimler Dergisi, 26(2), $1-25$.

Başaran, B. I. (2004). Etkili öğrenme ve çoklu zekâ kuramı: Bir inceleme. Ege Ë̆itim Dergisi, 5(1), 7-15. 
Başol, O., Dursun, S. ve Aytaç, S. (2011). Kişiliğin girişimcilik niyeti üzerine etkisi: üniversiteli gençler üzerine bir uygulama. "Işs, Güç" Endüstri İlişkileri ve İnsan Kaynakları Dergisi, 13(4), 7-22.

Behlau, S. (2010). Life satisfaction: A study of undergraduate and graduate students [Theses of Master, The Graduate School at Rowan University].

Research Direct. https://rdw.rowan.edu/etd/36

Bingham, W. V. (1937). Aptitudes and aptitude testing. Harper \& Brothers, New York.

Bird, B. (1988). Implementing entrepreneurial ideas: The case for intention. Academy of management Review, 13(3), 442-453.

https://doi.org/10.5465/amr.1988.4306970

Bümen, T. N. (2004). Okulda çoklu zekâ kuramı. 2. Baskı. Pegem A Yayıncılık.

Cummins, R. A. (1998). The second approximation to an international standard for life satisfaction. Social Indicators Research, 43(3), 307-334.

https://doi.org/10.1023/A:1006831107052

Çelik, A., İnce, M. ve Bozyiğit, S. (2014). Üniversite öğrencilerinin girişimcilik niyetlerini etkileyen ailesel faktörleri belirlemeye yönelik bir çalışma. Niğde Üniversitesi Íktisadi ve İdari Bilimler Fakültesi Dergisi, 7(3), 113124.

Çetin, O. ve Taşdemir, Ö. (2017). Girişimcilik kapasitesi ve bireysel yenilikçiliğin girişimcilik niyeti üzerine etkisi. Sosyal Bilimler Araştırma Dergisi, 6(3), 76-87.

Çevik, N. K. ve Korkmaz, O. (2014). Türkiye'de yaşam doyumu ve iş doyumu arasındaki ilişkinin iki değişkenli sıralı probit model analizi. Niğde Üniversitesi İktisadi ve İdari Bilimler Fakültesi Dergisi, 7(1), 126-145.

Çiçek, R. ve Durna, U. (2012). Meslek idealleri ve girişimcilik niyetleri. Mustafa Kemal Üniversitesi Sosyal Bilimler Enstitüsü Dergisi, 9(17), 17-31.

Dastmalchian, A., Blyton, P. and Adamson, R. (2014). The Climate of Workplace Relations (Routledge Revivals). Routledge.

Dehdashti Lesani, M., Makvandi, B., Naderi, F. and Hafezi, F. (2020). Relationship of self-differentiation and social intelligence with happiness 
by mediating role of difficulty in cognitive emotion regulation among female-headed households. Middle East Journal of Rehabilitation and Health Studies, 7(3), 1-7. https://doi.org/10.5812/mejrh.103840

Demirel, E. T. ve Tikici, M. (2010). Üniversite öğrencilerinin girişimcilik özelliklerinin beyin baskınlı analizi ile değerlendirilmesi: İnönü üniversitesi İ̈BF işletme bölümü örneği. Elektronik Sosyal Bilimler Dergisi, 9(32), 221-253.

Demirel, E. T., Düşükcan, M. ve Ölmez, M. (2011). Çoklu zekâ alanlarının girişimcilik davranışına etkisi. Organizasyon ve Yönetim Bilimleri Dergisi, 3(2), 97-105.

Deniz, M. (2006). The relationships among coping with stress, life satisfaction, decision-making styles and decision self-esteem: An investigation with Turkish university students. Social Behavior and Personality: An International Journal, 34(9), 1161-1170.

https://doi.org/10.2224/sbp.2006.34.9.1161

Dewey, J. (1909). Moral Principles in Education. Houghton Mifflin.

Diener, E. D., Emmons, R. A., Larsen, R. J. and Griffin, S. (1985). The satisfaction with life scale. Journal of personality assessment, 49(1), 7175.

https://doi.org/10.1207/s15327752jpa4901 13

Diener, E., Gohm, C. L., Suh, E. and Oishi, S. (2000). Similarity of the relations between marital status and subjective well-being across cultures. Journal of Cross-Cultural Psychology, 31(4), 419-436.

https://doi.org/10.1177/0022022100031004001

Doğan, T. ve Çetin, B. (2009). Tromso sosyal zekâ ölçeği Türkçe formunun faktör yapısı, geçerlik ve güvenirlik çalışması. Educational Sciences: Theory and Practice, 7(1), 241-268.

Doğan, T. ve Eryılmaz, A. (2014). The role of social intelligence in happiness. Croatian Journal of Education: Hrvatski Časopis za Odgoj i Obrazovanje, 16(3), 863-878.

Dost, M. T. (2007). Üniversite öğrencilerinin yaşam doyumunun bazı değişkenlere göre incelenmesi. Pamukkale Üniversitesi Ĕ̈itim Fakültesi Dergisi, 22(22), 132-143. 
Durak, İ. (2018). Girişimcilik niyeti ile duygusal zekâ ve bazı sosyo-demografik değişkenler arasındaki ilişki: üniversite öğrencileri üzerine bir araştırma. MANAS Sosyal Araştırmalar Dergisi, 7(1), 281-297.

Ebrahimpoor, H., Zahed, A. and Elyasi, A. (2013). The study of relationship between social intelligence and organizational performance (Case study: Ardabil regional water company's managers). International Journal of Organizational Leadership, 2(1), 1-10.

Engle, R. L., Nikolay, D., Jose, V. G., Christopher, S., Servane, D., Irene, A., ... and Birgitta, W. (2008). Entrepreneurial intent: A twelve-country evaluation of Ajzenâ€ ${ }^{\mathrm{TM}}$ s model. International Journal of Entrepreneurial Behaviour \& Research, 16(1), 36-52.

Ferrante, F. (2005). Revealing entrepreneurial talent. Small Business Economics, 25(2), 159-174. https://doi.org/10.1007/s11187-003-6448-6

Ferreira, J. J., Raposo, M. L., Rodrigues, R. G., Dinis, A. and do Paço, A. (2012). A model of entrepreneurial intention: An application of the psychological and behavioral approaches. Journal of Small Business and Enterprise Development, 19(3), 424-440.

https://doi.org/10.1108/14626001211250144

Goldings, H. J. (1954). On the avowal and projection of happiness. Journal of Personality, 23, 30-47.

https://doi.org/10.1111/j.1467-6494.1954.tb02336.x

Goleman, D. (2007). Social Intelligence, Random House.

Goleman, D. (2019). Sosyal Zekâ İnsan İlişkilerinin Yeni Bilimi. 8. Baskı, (Çev.: O. Deniztekin), Varlık Yayınları.

Habib, S., Saleem, S. and Mahmood, Z. (2013). Development and validation of social intelligence scale for university students. Pakistan Journal of Psychological Research, 28(1), 65-83.

Hair, F. J., Black, C. W., Babin, J. B. and Anderson, E. R. (2014). Multivariate Data Analysis. 7. Ed. Pearson Education Limited. Essex.

Hisrich, R., Langan-Fox, J. and Grant, S. (2007). Entrepreneurship research and practice: a call to action for psychology. American psychologist, 62(6), 575. https://doi.org/10.1037/0003-066X.62.6.575 
Honarmand, M. M. Z., Naami, A. and Roshani, K. (2014). Surveying the Role of Social Intelligence and its Components in Life Satisfaction of Elderlies. International Journal of Psychology and Behavioural Research, 3(3), 192197.

Haybron, D. M. (2000). Two philosophical problems in the study of happiness. Journal of Happiness Studies, 1(2), 207-225.

https://doi.org/10.1023/A:1010075527517

Işık, M. ve Çiçek, B. (2020). Planlı davranış teorisi perspektifinden girişimcilik niyeti üzerinde sosyal sermaye, öz yeterlilik ve öz saygının rolü. Turkish Studies-Economics, Finance, Politics, 15(1), 185-206.

Işık, M. (2019, Mayıs 2-5). Üniversite İkliminin Girişimcilik Eğilimine Etkisi [Sözlü sunum]. Uluslararası İktisadi ve İdari Bilimler Kongresi, Şırnak. https://kongre.akademikiletisim.com/files/javs2019/javs_tam_metin_kita bi.pdf

İlhan, M. ve Çetin, B. (2014). Sosyal ve kültürel zekâ arasındaki ilişkinin yapısal eşitlik modeli ile incelenmesi. Turkish Journal of Education, 3(2), 4-15.

https://doi.org/10.19128/turje.181078

James, W. (1950). The principles of psychology, Vol. 2. New York.

Jan, M. and Masood, T. (2008). An assessment of life satisfaction among women. Studies on Home and Community Science, 2(1), 33-42.

https://doi.org/10.1080/09737189.2008.11885250

Joseph, C. and Lakshmi, S. S. (2010). Social Intelligence, a Key to Success. IUP Journal Of Soft Skills, 4(3), 15-21.

Kahya, C. ve İmamoğlu, İ. K. (2015). Ekonomi okuryazarlı̆̆ının girişimcilik niyeti üzerindeki rolü. The Journal of Academic Social Science Studies, 39, 139-156.

Kahya, V. ve Ceylan, E. (2017). The effect of interpersonal intelligence levels on the entrepreneurship potential: a research on university students. PressAcademia Procedia, 3(1), 867-874.

https://doi.org/10.17261/Pressacademia.2017.667 
Kalkan, A. (2011). Kişisel tutum, öznel norm ve algılanan davranış kontrolünün girişimcilik niyeti üzerindeki etkisi: üniversite öğrencileri üzerine bir uygulama. Süleyman Demirel Üniversitesi Sosyal Bilimler Enstitüsü Dergisi, (14), 189-206.

Kellermanns, F. W. and Eddleston, K. A. (2006). Corporate entrepreneurship in family firms: A family perspective. Entrepreneurship Theory and Practice, 30(6), 809-830.

https://doi.org/10.1111/j.1540-6520.2006.00153.x

Keser, A. (2005). İş doyumu ve yaşam doyumu ilişsisi: Otomotiv sektöründe bir uygulama. Çalışma ve Toplum, 4(1), 77-95.

Khan, T. and Bhat, S. (2017). Social intelligence, life satisfaction and depressive symptoms among adult women. International Journal of Indian Psychology, 4(3), 35-40.

Kihlstrom, F. J. and Cantor, N. (2011). Social Intelligence. In R. J. Sternberg \& S. B. Kaufman (Eds.), Cambridge handbooks in psychology. The Cambridge Handbook of Intelligence (pp. 564-581). Cambridge University Press.

Kosmitzki, C. and John, O. P. (1993). The implicit use of explicit conceptions of social intelligence. Personality and Individual Differences, 15(1), 11-23.

https://doi.org/10.1016/0191-8869(93)90037-4

Legg, S. and Hutter, M. (2007). A collection of definitions of intelligence. Frontiers in Artificial Intelligence and applications, 157(17), 1-11.

Lorenz, E. H. (1992). Trust and the flexible firm: international comparisons. Industrial Relations: A Journal of Economy and Society, 31(3), 455-472.

https://doi.org/10.1111/j.1468-232X.1992.tb00320.x

Marlowe, H. A. (1986). Social intelligence: Evidence for multidimensionality and construct independence. Journal of educational psychology, 78(1), 5258. https://doi.org/10.1037/0022-0663.78.1.52

Matheny, K. B., Curlette, W. L., Aysan, F., Herrington, A., Gfroerer, C. A., Thompson, D. and Hamarat, E. (2002). Coping resources, perceived stress, and life satisfaction among Turkish and American university students. International Journal of Stress Management, 9(2), 81-97. 
https://doi.org/10.1023/A:1014902719664

Mueller, S. L. and Dato-On, M. C. (2008). Gender-role orientation as a determinant of entrepreneurial self-efficacy. Journal of Developmental Entrepreneurship, 13(01), 3-20.

https://doi.org/10.1142/S108494670800082X

Mueller, S. L. and Thomas, A. S. (2001). Culture and entrepreneurial potential: A nine country study of locus of control and innovativeness. Journal of Business Venturing, 16(1), 51-75.

https://doi.org/10.1016/S0883-9026(99)00039-7

Naktiyok, A. ve Timuroğlu, M. K. (2009). Öğrencilerin motivasyonel değerlerinin girişimcilik niyetleri üzerine etkisi ve bir uygulama. Atatürk Üniversitesi İktisadi ve İdari Bilimler Dergisi, 23(3), 85-103.

Neuringer, C. (1991). The social intelligence of acting students. The Journal of Psychology, 125(5), 549-556.

https://doi.org/10.1080/00223980.1991.10543319

Orlik, P. (1978). Soziale intelligenz [Social intelligence]. Handbuch der Pädagogischen Diagnostik [Handbook of Pedagogical Diagnostics], 341354.

Özdevecioğlu, M. (2004). Sosyal destek ve yaşam tatmininin mesleki stres üzerindeki etkileri: Kayseri'de faaliyet gösteren işletme sahipleri ile bir araştirma. Hacettepe Üniversitesi İktisadi ve İdari Bilimler Fakültesi Dergisi, 22(1), 209-233.

Özdevecioğlu, M. ve Aktaş, A. (2007). Kariyer bağl1lığı, mesleki bağl1lık ve örgütsel bağl1lığın yaşam tatmini üzerindeki etkisi: İş-aile çatışmasının rolü. Erciyes Üniversitesi İktisadi ve İdari Bilimler Fakültesi Dergisi, (28), $1-20$.

Özgür, G., Babacan Gümüş, A. ve Durdu, B. (2010). Evde ve yurtta kalan üniversite öğrencilerinde yaşam doyumu. Psikiyatri Hemşireliği Dergisi, $1(1), 25-32$.

Özler, N. D. E., Giderler, C. ve Baran, H. (2017). Öz yeterlilik ve kontrol odağının bireylerin girişimcilik niyeti üzerindeki etkisini belirlemeye yönelik bir araştırma. Uluslararası Yönetim Ikktisat ve Işsletme Dergisi, 13(13), 736-747. 
Parales-Quenza, C. J. (2006). Astuteness, Trust, and Social Intelligence. Journal for the theory of social behaviour. Journal for the Theory of Social Behavior, 36(1), 39-56.

https://doi.org/10.1111/j.1468-5914.2006.00295.x

Parlak, K. (2013). Girişimci kişilik özelliklerine sahip olmak ile kendini ve başkalarını tanıma (içsel ve sosyal) zekâları arasındaki ilişkinin incelenmesi. IZU Social Sciences Journal, 2(3), 55-64.

Pekkan, N. U. ve Sisman, G. (2020). Predicting the entrepreneurial intention: a moderated mediation model. International Journal of Management and Enterprise Development, 19(3), 217-235.

https://doi.org/10.1504/IJMED.2020.108712

Rashid, U. K., Nik Mat, N. K., Ma'rof, R. A., Nasuredin, J., Sanita, F. and Mohamed Isa, M. F. (2012). Entrepreneurial intentions among technical students. American Journal of Economics. American Journal of Economics, Special Issue, 73-76.

https://doi.org/10.5923/j.economics.20120001.17

Salovey, P. and Mayer, J. D. (1990). Emotional intelligence. Imagination, Cognition and Personality, 9(3), 185-211.

https://doi.org/10.2190/DUGG-P24E-52WK-6CDG

Schmitt, N. and Pulakos, E. D. (1985). Predicting job satisfaction from life satisfaction: Is there a general satisfaction factor?. International Journal of Psychology, 20(2), 155-167.

https://doi.org/10.1080/00207598508247729

Sciascia, S. and De Vita, R. (2004). The development of entrepreneurship research. Università Carlo Cattaneo.

Siedlecki, K. L., Tucker-Drob, E. M., Oishi, S. and Salthouse, T. A. (2008). Life satisfaction across adulthood: Different determinants at different ages?. The Journal of Positive Psychology, 3(3), 153-164.

https://doi.org/10.1080/17439760701834602 
Silvera, D., Martinussen, M. and Dahl, T. I. (2001). The Tromsø Social Intelligence Scale, a self-report measure of social intelligence. Scandinavian Journal of Psychology, 42(4), 313-319.

https://doi.org/10.1111/1467-9450.00242

Sousa, L. and Lyubomirsky, S. (2001). Life satisfaction. Encylopedia of women and gender: Sex similarities and differences and the impact of society on gender Vol. 2, 667-676.

Spatar, H. M. (1995). Zekâ testlerinin serüveni. Bilim ve Ütopya, 10(16), 6-9.

Stevenson, B. and Wolfers, J. (2013). Subjective well-being and income: Is there any evidence of satiation?. American Economic Review, 103(3), 598-604.

https://doi.org/10.1257/aer.103.3.598

Şeşen, H. ve Basım, H. N. (2012). Demografik faktörler ve kişiliğin girişimcilik niyetine etkisi: Spor bilimleri alanında öğrenim gören üniversite öğrencileri üzerine bir araştırma. Ege Akademik Bakış, 12, 21-28.

Thorndike, E. L. (1920). Intelligence and its uses. Harper's magazine. 140, 227235.

Thorndike, R. L. and Stein, S. (1937). An evaluation of the attempts to measure social intelligence. Psychological Bulletin, 34(5), 275-285.

https://doi.org/10.1037/h0053850

Timuroğlu, M. K. ve Akpunar, E. N. (2017). Duygusal zekânın girişimcilik niyeti üzerine etkisi. Ataturk University Journal of Economics \& Administrative Sciences, 31(4), 875-894.

Tümkaya, S., Hamarta, E., Deniz, M. E., Çelik, M. ve Aybek, B. (2008). Duygusal zekâ mizah tarzı ve yaşam doyumu: Üniversite öğretim elemanları üzerine bir araştırma. Türk Psikolojik Danışma ve Rehberlik Dergisi, 3(30), 1-18.

Ural, A., ve K1lıç, İ. (2013). Bilimsel araştırma süreci ve spss ile veri analizi, 4. Bask1, Detay Yayınc1lık.

Uslan, Y. U. (2016). Public employee'job satisfaction, life satisfaction and burnout levels' assessment by some socia-demographic factors Kamu çalışanlarının iş doyumu, yaşam doyumu ve tükenmişlik düzeylerinin bazı 
sosyo-demografik unsurlara göre değerlendirilmesi. Journal of Human Sciences, 13(2), 3354-3372.

Uyguç, N., Arbak, Y., Duygulu, E. ve Çıraklar, N. H. (1998). İş ve yaşam doyumu arasındaki ilişkinin üç temel varsayım altında incelenmesi. Dokuz Eylül Üniversitesi İktisadi İdari Bilimler Fakültesi Dergisi, 13(2), 193-204.

Hülya, U., Buran, A. Ç. ve Beydilli, E. T. (2017). Sosyal zekânın girişimcilik niyeti üzerindeki etkisi: meslek yüksekokulu öğrencileri üzerinde bir araştırma. Siyaset Ekonomi ve Yönetim Araştırmaları Dergisi, 5(5), 1-13.

https://doi.org/10.25272/j.2147-7035.2017.5.5.01

Veenhoven, R. (1996). The study of life-satisfaction. Eötvös University Press, 11-48.

Veenhoven, R. (2000). The four qualities of life. Journal of Happiness Studies, 1(1), 1-39. https://doi.org/10.1023/A:1010072010360

Walker, R. E. and Foley, J. M. (1973). Social intelligence: Its history and measurement. Psychological Reports, 33(3), 839-864.

https://doi.org/10.2466/pr0.1973.33.3.839

Wawra, D. (2009). Social intelligence: The key to intercultural communication. European Journal of English Studies, 13(2), 163-177.

https://doi.org/10.1080/13825570902907193

Yavuz, K. E. (2001). Ĕgitim-öğretimde çoklu teorisi ve uygulamaları, 3. Bask1, Özel Ceceli Okulları Yayınları.

Yıldırım, F., Naktiyok, S. ve Kula, M. E. (2016). Tükenmişlik düzeyinin girişimcilik niyeti üzerine etkisi. İşletme Araştırma Dergisi, 8, 15-33.

Yılmaz, G., Keser, A. ve Yorgun, S. (2010). Konaklama işletmelerinde çalışan sendika üyelerinin iş ve yaşam doyumunu belirlemeye yönelik bir alan araştırmas1. Paradoks Ekonomi Sosyoloji ve Politika Dergisi, 6(1), 87-107.

Zampetakis, L. A., Kafetsios, K., Bouranta, N., Dewett, T. and Moustakis, V. S. (2009). On the relationship between emotional intelligence and entrepreneurial attitudes and intentions. International Journal of Entrepreneurial Behavior \& Research, 15(6), 595-618. 
I.Bakan-H.Amırlı Girișimcilik Niveti ve Yașam Doyumunun...

İnternet Kaynakları

Türk Dil Kurumu. https://sozluk.gov.tr/ 